\title{
Thomas Lewis, Fari Amini, Richard Lannon, A General Theory of Love, Vintage Books, New York 2007, ss. 274
}

Pod pewnymi warunkami jest możliwe omawianie złożonych zjawisk w sposób ograniczony, jednoznaczny, a przy tym - paradoksalnie - mimo wszystko satysfakcjonująco wyczerpujący. Może to być możliwe, dzięki zastosowaniu konsekwentnej metodologii, dzięki której z jednej strony możliwie będą dokładne starania zmierzające do objęcia danego zagadnienia najbardziej wieloaspektowo, $\mathrm{z}$ drugiej zaś strony nastąpi zawężanie wniosków otrzymanych na podstawie opracowania danych, płynących z różnych dziedzin wiedzy. Taką metodologię oferuje kognitywistyka, do której zadań należy badanie aparatu poznawczego człowieka oraz dążenie do osiągnięcia syntezy wiedzy na temat umysłu, co przekłada się na ujmowanie badanych zagadnień z możliwie wielu stron. Na przykład poprzez badanie podłoża neurobiologicznego, psychologicznego czy psychoewolucyjnego danego zjawiska, poprzez podejmowanie prób odtworzenia jego struktury, stosując metodę inżynierii odwrotnej. Stosowana jest tu także symulacja zjawiska, refleksja filozoficzna nad nim, a także odnoszenie się do niego poprzez porównania z przykładami czerpanymi ze świata zwierząt (na przykład w badaniach biologicznych związanych $\mathrm{z}$ emocjami, zachowaniami, sposobami przetwarzania informacji). Takie wieloaspektowe badanie jakiegoś zjawiska określa się jako konwergencję. Pozwala ono, dzięki uzyskaniu różnorodnych danych o danym zjawiska, na ograniczenie jego interpretacji, co w założeniu ma prowadzić do wyjaśnienia jego istoty w możliwie jednoznaczny sposób ${ }^{1}$.

${ }^{1}$ K. N. Ochsner, S. M. Kosslyn, Cognitive Neuroscience: Where Are We Now?, [w:] The Oxford Handbook of Cognitive Neuroscience, Volume 2: The Cutting Edges, red. K. N. Ochsner, S. M. Kosslyn, Oxford University Press, New York 2016, s. 3-4. 
W duchu takiej metodologii, na temat istoty miłości, prowadzone są rozważania przez autorów książki A General Theory of Love - Thomasa Lewisa, Fari Amini oraz Richarda Lannona, trójki psychiatrów, pokoleniem reprezentujących trzy różne okresy rozwoju psychiatrii (podejście psychoanalityczne, psychofarmakologiczne oraz psychodynamiczne zderzone $\mathrm{z}$ ujęciem neurobiologicznym). Powołując się na bardzo bogate badania $z$ wielu dziedzin wiedzy (jak choćby wspomniana psychologia ewolucyjna oraz inżynieria odwrotna), wymienieni uczeni dążą do uzyskania zawężonej interpretacji tego, czym jest miłość między dwojgiem ludzi.

Książka koncentruje się na przedstawieniu miłości (w sensie minimalnym) jako (1) opiekowania się drugą osobą, (2) zapewnienia jej schronienia i poczucia bezpieczeństwa, (3) lojalności wobec niej oraz (4) poświęcania się dla niej. Bez tych czterech cech (czy też zasad) zdaniem autorów nie można mówić o miłości, zaś ich istnienie może być zapewnione jedynie przy obecności układu limbicznego w mózgu (który jest charakterystyczną częścią układu nerwowego ssaków) i to dzięki jego optymalnemu rozwojowi (poprzez mechanizm limbicznego rezonansu, limbicznej regulacji i limbicznej rewizji). Mechanizmy te, według autorów, przyczyniają się do rozwinięcia zdolności do rozumienia (a także rozpoznawania) miłości w sensie minimalnym, opartej na wymienionych wyżej czterech zasadach. W dalszej części recenzji przedstawię rozważania autorów nad specyfiką aparatu poznawczego człowieka i jego konsekwencji dla miłości, które zostaną sprowadzone do czynionych przez autorów odniesień do trzech kluczowych dla nich mechanizmów: limbicznego rezonansu, regulacji i rewizji.

Początkowe rozdziały książki poświęcone zostały podstawowemu problemowi, który utrudnia zaistnienie „optymalnej” miłości. Chodzi o wykształcenie zdolności do rozpoznawania tego, jaki partner będzie dla nas odpowiedni. Problem ten, według Lewisa i jego współpracowników, ma swoje źródło w organicznej strukturze naszego mózgu oraz w jego kształtowaniu $\mathrm{w}$ relacjach $\mathrm{z}$ innymi ludźmi. Ludzki mózg w kolejnych etapach rozwoju filogenetycznego ulegał rozrostowi i nieharmonijnym przemianom, które doprowadziły do jego trójdzielnej, strukturalnie i funkcjonalnie rozwarstwionej, zróżnicowanej budowy. Ewolucyjne zmiany doprowadziły do powstania trzech obszarów: „mózgu gadziego” (do którego należy śródmózgowie i pień mózgu), układu limbicznego oraz kory nowej. Gadzi mózg, pierwsza ewolucyjnie wykształcona część ludzkiego mózgu, ma niewiele wspólnego z życiem emocjonalnym wiązanym z miłością, jak podkreślają autorzy. Oprócz podtrzymywania bicia naszego serca i rytmu oddechu, odpowiada za prostsze 
interakcje pomiędzy osobnikami związane $\mathrm{z}$ osiągnięciem celu spłodzenia potomstwa, takie jak obrona terytorium, okazywanie agresji wobec konkurentów, zaloty czy krycie samicy. Kolejną pojawiającą się w toku ewolucji częścią mózgu, jest znajdujący się nad pniem mózgu i śródmózgowiem układ limbiczny. Jak dalej będą o tym przekonywać autorzy, nawiązując do takich mechanizmów jak limbiczny rezonans, limbiczna regulacja czy limbiczna rewizja, układ limbiczny stanowi kluczowy element odpowiadający za zdolność do kochania drugiego człowieka. Jest tak, ponieważ wraz z pojawieniem się tego układu u zwierząt, pojawiła się także nowa jakość w relacji pomiędzy matką a potomstwem, czyli zdolność do opieki, „zorientowanie na potomstwo", zapewnienie schronienia i poczucia bezpieczeństwa, poświęcenie i lojalność, a więc kluczowe dyspozycje ujawniające się wtedy, gdy kogoś kochamy i gdy ktoś kocha nas. Ostatnia i najnowsza część „trójjednego mózgu” (triune brain), to kora nowa. Odpowiada ona między innymi za zdolność do tworzenia mowy, za umiejętność pisania, planowania, wnioskowania czy za kontrolę motoryczną.

Funkcje mózgu wyższego (kory nowej) oraz niższego (pień, śródmózgowie) utrudniają mózgowi środkowemu (układ limbiczny) „dojście do głosu”. Posługując się tylko zdolnością myślenia, intelektualnie (co jest domeną kory nowej), nie jesteśmy w stanie rozpoznawać podstaw miłości oraz wpływać na siebie i na innych (obdarzając ich naszą miłością) w taki sposób, by okazać im miłość wyrażającą się poprzez wymienione cztery cechy. Z kolei gadzi pień mózgu jest emocjonalnie zbyt prymitywny, by tego dokonać. Rozpatrując miłość jedynie z perspektywy intelektualnej, według autorów, możemy popaść w „błąd pankognitywny”. Może nam się wydawać, że wszystko, czym jesteśmy, to myślenie, intelekt, że to głównie dzięki niemu poznajemy i przezeń jesteśmy aktywni w świecie. Tymczasem intelekt nie jest w stanie przejąć tego co emocjonalne, limbiczne. Intelekt nie dociera do niewerbalnych podstaw miłości. Co zatem jest odpowiedzialne za komunikację emocjonalną?

Różni naukowcy, korzystając z podejścia kognitywistycznego, starali się zidentyfikować różne uniwersalne mechanizmy odpowiedzialne za naszą zdolność do rozumienia wewnętrznego świata innych osób, w tym świata emocjonalnego. Do owych mechanizmów zalicza się między innymi aktywność neuronów lustrzanych (aktywnych w czasie obserwacji czynności wykonywanych przez inne osobniki, odzwierciedlające zachowania, jakie mógłby wykonać osobnik obserwujący), wrażliwość na prozodię (tonalność, melodię głosu, co pozwala nam na rozpoznanie emocjonalnych aspektów mowy), uniwersalna, niezależna od kultury zdolność do identyfikacji siedmiu pod- 
stawowych wyrazów twarzy (wyrażających radość, smutek, wstręt, strach, pogardę, zaskoczenie i gniew) czy teoria umysłu (pozwalająca na przyjęcie perspektywy innej osoby).

Jednak kluczowy dla Lewisa i współpracowników mechanizm odpowiedzialny za zdolność do rozpoznawania stanów emocjonalnych u innych osób, zdolność „widzenia” czyichś emocji i „dostrojenia się" do nich nazywany jest limbicznym rezonansem, który opisują alegorycznie jako „symfonię wzajemnej wymiany i wewnętrznej adaptacji, gdzie dwa ssaki stają się dostrojone nawzajem do swoich wewnętrznych stanów"2. Mechanizm ten jest szczególnie ważny ze względu na funkcję, jaką pełni w miłości. Ponieważ posiadamy wykształcone wzorce odczuć należących do bycia w relacji (cztery cechy miłości), nabyte dzięki interakcji z opiekunami, dysponujemy zdolnością do rozpoznania u innej osoby takich samych cech (inna osoba również posiada adekwatny wzorzec miłości), a wówczas miłość między dwojgiem ludzi może osiągnąć jedyny właściwy (według autorów) stan, w którym jest ona interpretowana jako cztery wcześniej wspomniane cechy. To rozpoznanie ma jednak wymiar niewerbalny, nieświadomy, intuicyjny i automatyczny, przez co wybieramy sobie takich partnerów, u których znajdujemy wzorzec podobny do naszego. Nie jesteśmy w stanie postąpić inaczej, niejako niezgodnie ze sobą, ponieważ rozpoznajemy tylko takie wzorce, jakie sami posiadamy i tylko na nie jesteśmy w stanie odpowiedzieć. Jak podkreślają autorzy, może to być problematyczne. Jeżeli każdy z partnerów posiada wzorzec odbiegający od standardu zapewniania Opieki-Schronienia-Lojalności-Poświęcenia (OSLP), to „miłość" między nimi zawsze doprowadzi do dysharmonijnej relacji.

Drugi wyróżniony przez autorów omawianej książki mechanizm, to limbiczna regulacja, którą określają jako „wzajemną synchronizującą wymianę reakcji neurofizjologicznych pomiędzy dwoma osobnikami”3. Przytaczają przy tym badania Myrona Hofera z 1987 roku przeprowadzone na szczurach. Celem tych badań było zidentyfikowanie takich cykli biologicznych regulowanych przez mózg młodych szczurów, do wykształcenia których nie jest konieczna opieka matki. Okazało się, że nie ma takich cykli. Matka nieustannie poprawia, dostosowuje, reguluje i wpływa na układy biologiczne swojego potomstwa: na system behawioralny (poziom aktywności), układy związane $\mathrm{z}$ karmieniem (ssanie), układy neurochemiczne (poziomy dopaminy, nore-

${ }^{2}$ T. Lewis, F. Amini, R. Lannon, A General Theory of Love, Vintage Books, New York 2007, s. 61, (wszystkie cytaty pochodzące z tej książki są tłumaczeniem własnym).

3 T. Lewis, F. Amini, R. Lannon, dz. cyt., s. 82. 
pinefryny, opiatów), metaboliczne (konsumpcja tlenu), snu (fazy snu REM, cykle cyrkadialne), na układ krążenia (rytm bicia serca, zmiany w zwężaniu się i rozszerzaniu się naczyń), układ endokrynologiczny (regulujący poziom hormonów wzrostu, kortykosteronu) i układy immunologiczne. Doniosłość wyników tych badań, jak podkreślają autorzy, zawiera się w tym, że pokazują one ogromną rolę, jaką u ssaków odgrywa regulacja ze strony opiekunów. $\mathrm{W}$ istocie system neurofizjologiczny ssaków do wykształtowania się jego stabilnej postaci wymaga interakcji z innym osobnikami, z którymi łączą go relacje przywiązania, na późniejszym etapie pozwalające na autonomiczne funkcjonowanie potomstwa. Podobnie dzieje się w przypadku wykształcania wzorców limbicznych u dzieci w interakcji z opiekunami. Bardzo małe dzieci nie są w stanie samodzielnie regulować swojej aktywności emocjonalnej, w kluczowych momentach potrzebują ukojenia ze strony matki, a gdy coś jest nie tak, odwołują się do niej, kiedy nie są pewne, jak zinterpretować to, co im się przydarza (na przykład, gdy przewracają się, to spoglądają na twarz matki, która uśmiechając się lub ukazując zaniepokojenie, pokazuje im, na ile to co się stało, jest poważne). Dziecko stanowi „maksymalnie otwartą pętlę fizjologiczną" ", która bez limbicznej regulacji ze strony opiekunów, nie jest w stanie przetrwać. Dzięki początkowej regulacji ze strony matki, dziecko będzie w stanie później regulować się samodzielnie, łagodząc własne emocje czy optymalnie wchodząc $\mathrm{w}$ interakcje $\mathrm{z}$ innymi. W bliskich relacjach interpersonalnych wzajemna regulacja jest nieunikniona, a osiągnięcie stabilności w związku oznacza znalezienie kogoś, kto w dobry sposób nas „reguluje”, jak konkludują autorzy.

Powstaje pytanie: czy i jak możliwe jest naprawienie zawartych w nas wzorców związanych z miłością? Odpowiedź, według autorów, tkwi w mechanizmie limbicznej rewizji, w ostatnim z trzech mechanizmów limbicznych, polegającym na zmianach w obrębie pamięci niejawnej ${ }^{5}$ i w aktywacjach atraktorów $w^{6}$ dzięki intymnej relacji $\mathrm{z}$ drugą osobą. Zmiany owe $\mathrm{w}$ istocie polegają na modyfikacji siły połączeń $\mathrm{w}$ różnych konfiguracjach neuronalnych w mózgu. Istnieje mniejsze prawdopodobieństwo aktywacji jakiegoś wzorca neuronalnego w odpowiedzi na jakiś bodziec, jeżeli siła połączeń pomiędzy neuronami jest w nim słabsza, niż w konkurencyjnym wzorcu, który również

\footnotetext{
${ }^{4}$ Tamże, s. 83.

${ }^{5}$ Pamięć niejawna jest związana z naszymi reakcjami, z których przyczyn nie zdajemy sobie sprawy, choć to na ich podstawie podejmujemy decyzje.

${ }^{6}$ Atraktory są to zapamiętane wzorce utrwalone w mózgu, które pozwalają na odpowiednie automatyczne działanie bądź na automatyczne przetwarzanie informacji, w reakcji na bodziec.
} 
ma szansę aktywować się w przypadku obecności tego samego bodźca. Jeżeli na przykład mamy niejednoznaczny bodziec, który może być odczytany jako litera „A” bądź „H”, to w przypadku przewagi siły połączeń we wzorcu neuronalnym odczytującym taki niejednoznaczny bodziec jako „A” (względem tego, który odczytuje go jako $\mathrm{H}$ ) będzie istniało większe prawdopodobieństwo, że odczytamy taki bodziec jako „A” niż „H”. Na tym właściwie polega pamięć. Jest ona procesem zmiany siły połączeń w konfiguracjach neuronalnych w mózgu, co przekłada się na zmianę prawdopodobieństwa aktywacji jakiegoś konkretnego wzorca neuronalnego w przyszłości w odpowiedzi na jakiś bodziec. Zatem to, co robi terapeuta, to zmiana w obrębie procesów pamięciowych pacjenta. Przykładowo, jeżeli ktoś inicjuje wobec pacjenta intymną relację opartą na zaufaniu, to rolą terapeuty jest zmniejszenie prawdopodobieństwa tego, że pacjent zareaguje $\mathrm{w}$ takim przypadku wyuczoną reakcją lękową, bądź opartą na odrzucaniu, a zwiększy tę polegającą na byciu otwartym na nowe doznania i odwzajemnianiu zaufania ${ }^{7}$. Wobec tego można zauważyć, że istotą zmiany dokonującej się w nas samych, w naszej psychice, będzie dokonywanie zmian w aktywowanych wzorcach i zmiany w prawdopodobieństwie aktywności tych wzorców (starych i nowych). Proces psychoterapii korzysta w tym celu ze wszystkich trzech limbicznych mechanizmów: rezonansu, regulacji i rewizji. Lewis i współpracownicy stwierdzają, że psychoterapia jest czymś bardzo neurofizjologicznym. Psychoterapeuta musi dostroić się do stanów wewnętrznych pacjenta (drogą limbicznego rezonansu), następnie dokonać ich regulacji (co możliwe będzie tylko wtedy, gdy pacjent zrezygnuje z własnej autonomii i zgodzi się być zależnym od terapeuty, czego skutkiem będzie wkroczenie na zupełnie nieznane mu terytorium - sieć emocjonalną prawdopodobnie nigdy nie występującą $\mathrm{w}$ jego życiu) i - ostatecznie - zmiany wzorców limbicznych pacjenta. Rewiduje je na mocy limbicznej rewizji i sprawia, że pacjent znów może stanąć na swoich „emocjonalnych nogach". Jednak tylko na tyle, na ile pozwalają wzorce uosobione przez terapeutę.

Przedstawiona w omawianej książce koncepcja mechanizmów limbicznych, które w sensie podstawowym są odpowiedzialne za nasze prawidłowe funkcjonowanie emocjonalne związane z miłością, wydaje się przekonująca i stanowi wartościowe uzupełnienie wiedzy nie tylko o intymnych relacjach interpersonalnych, ale także, w sensie ogólnym, wiedzy o mechanizmach po-

${ }^{7}$ Por. D. J. Siegel, The Developing Mind: How Relationships and the Brain Interact to Shape Who We Are, The Guilford Press, New York-London 2012, s. 46-51. 
znawczych konstytuujących nasze działanie. Informacje wstępne w obrębie każdego z rozdziałów napisane są lekkim, literackim stylem - to dodatkowy walor książki. Nie zmienia to faktu, że opracowanie reprezentuje wysoki poziom merytoryczny. Na uwagę zasługują szczegółowe odniesienia do badań empirycznych, które sprzyjają przystępnej prezentacji i nadają jej konwergentny charakter. Jako przykład można podać szczegółową i jasną prezentację reguły Hebba, w sposób, który czyni z niej świetny materiał źródłowy dla studentów poznających podstawy neurofizjologii.

Pewne kontrowersje budzi skłonność autorów do modelu mózgu trójjednego, opracowanego przez Paula MacLeana jeszcze w latach sześćdziesiątych. Autorzy zdają sobie z tego sprawę i bronią swojego stanowiska. Mimo to w tym punkcie czytelnik powinien raczej samodzielnie uzupełnić wiedzę dotyczącą obecnego statusu modelu MacLeana.

$\mathrm{Na}$ zakończenie warto zwrócić uwagę, że przedstawione przez autorów cztery cechy miłości (opisane jako OSLP) są oczywiście tylko pewnym modelem miłości. Autorzy zakładają, że nie da się określić jej istoty, ponieważ nie jest ona zjawiskiem należącym do poziomu werbalnego, nie można więc nigdy sformułować wyczerpującej definicji miłości. Można natomiast ją rozpoznawać, doświadczać jej i zmieniać się pod jej wpływem na poziomie limbicznym, emocjonalnym, pozajęzykowym. Pomimo pewności siebie, z jaką autorzy A General Theory of Love modelują miłość, pozostaje ona otwartym zagadnieniem, które wciąż stanowi pole dla kolejnych, bardziej dokładnych i rozbudowanych modeli, być może lepiej pozwalających uchwycić podstawowe składowe tego, co nazywamy „miłością”. Wprawdzie A General Theory of Love stanowi lekturę obowiązkową dla badaczy zajmujących się miłością, to jej głównym odbiorcą będzie każdy, kto chciałby zrozumieć lepiej siebie i swoje relacje $\mathrm{z}$ innymi, ponieważ kwestie związane z miłością, jak wynika $\mathrm{z}$ rozważań autorów, dotykają $\mathrm{w}$ sposób fundamentalny każdego $\mathrm{z}$ nas.

Wojciech Sak Uniwersytet Mikołaja Kopernika, Toruń, Polska e-mail: wojciech.r.sak@gmail.com 